KS. JÓZEF SZYMAŃSKI* - WŁOCŁAWEK

\title{
KS. WACŁAW TOKAREK - W SŁUŻBIE JEDNEGO KOŚCIOŁA
}

Od pierwszych dni po wyzwoleniu księża, którzy przebywali w obozach koncentracyjnych i jenieckich oraz na przymusowych robotach w Niemczech, podjęli posługę kapłańską wśród uwolnionych rodaków. Początkowo praca ta nie miała charakteru zorganizowanego. Kierując się celami swego powołania, ożywieni własną gorliwością, duchowni ci organizowali, początkowo każdy na własną rękę, pracę duszpasterską. W grudniu 1945 r. w 694 ośrodkach zaangażowanych było w sprawowanie posługi duszpasterskiej 502 kapłanów $^{1}$. Z biegiem czasu działalność poszczególnych duszpasterzy jak i zorganizowanych przez nich ośrodków duszpasterskich nabrała rozmachu pod względem organizacyjnym i różnorakich form, jak np. akcja charytatywna, akcja wydawnicza² ${ }^{2}$.

Jednym z tych duszpasterzy, który włączył się w akcję wydawniczą był ksiądz Tokarek Wacław, kapłan diecezji łódzkiej. Urodził się 15 stycznia 1914 r. w Łodzi. Był synem Józefa i Antoniny z d. Michalak. Do Szkoły Powszechnej uczęszczał początkowo w Garbowie, potem w Aleksandrowie, a następnie w Łodzi. Tamże w 1930 r. ukończył Gimnazjum Miejskie im. Józefa Piłsudskiego i podjął pracę na poczcie. W następnym roku podjął studia filozoficzno-teologiczne w Wyższym Seminarium Duchownym w Łodzi. 15 sierpnia 1936 r. w Łodzi z rąk bpa Włodzimierza Jasińskiego przyjął święcenia kapłańskie. Tegoż samego dnia został skierowany na dalsze studia $\mathrm{z}$ teologii dogmatycznej na Wydziale Teologicznym Uniwersytetu Warszawskiego. Od 1937 r. podjął również studia w Wyższej Szkole Dziennikarstwa. Od 11 września 1939 r. pełnił obowiązki tymczasowego wikariusza w parafii św. Mateusza w Pabianicach, rektora kościoła św. Floriana i kapelana szpitala. Tamże, 6 października 1941 r. został aresztowany przez Gestapo. Od 30 listopada 1941 r. był więziony w obozie koncentracyjnym w Dachau - nr obozowy 28460. Po wyzwoleniu przez 5 lat pracował dla Polaków w Monachium

\footnotetext{
* Ks. Józef Szymański - dr hab. historii, e-mail: szymaj63@wp.p1

${ }^{1}$ A. Nadolny, Opieka duszpasterska nad dziećmi i młodzieża polską na terenie Niemiec Zachodnich w latach 1945-1965, Lublin 1980, s. 29.

2 J.A. Radomski, Demobilizacja Polskich Sit Zbrojnych na Zachodzie w latach 1945-1951, Kraków 2009, s. 114-116.
} 
i okolicy, jako redaktor m.in. „Słowa Katolickiego”, , ,Słowa Polskiego”, biuletynu codziennego „Byle prędzej”, dwutygodnika dla dzieci „Słówko polskie”, niedzielnego biuletynu religijnego „Słowo Boże” i innych polskich czasopism tego okresu. Jednocześnie był też duszpasterzem akademickim. W 1950 r. wyjechał do Francji, gdzie redagował czasopisma: „Polska Wierna” i „Słowo Katolickie”. Używał pseudonimu „Żygota”. Pomagał w duszpasterstwie w Polskiej Misji Katolickiej w Paryżu. W 1969 r. powrócił na stałe do Niemiec i przez rok pracował jako kapelan sióstr niemieckich w Mannheim oraz pomagał w duszpasterstwie wśród Polaków w Kompanii Wartowniczej. Od 1 listopada 1970 r. przejął obowiązki proboszcza PMK w Dortmundzie. Podczas swego duszpasterzowania zabiegał o utworzenie polskiego domu katolickiego. Pełnił obowiązki dziekana dekanatu północnego. 10 grudnia 1986 r. przeszedł na emeryturę, pomagając nadal w duszpasterstwie wśród Polaków.

Odznaczony został Złotym Krzyżem Zasługi (1976).

Zmarł 2 lipca 1990 r. w Dortmundzie, gdzie został pochowany na cmentarzu Nordfriedhof ${ }^{4}$.

Ks. Tokarek podjął posługę duszpasterską wobec uwolnionych rodaków, bezpośrednio po wyzwoleniu z obozu koncentracyjnego w Dachau. Dzieląc ich tułaczy los, przede wszystkim poprzez słowo pisane, stwarzał możliwości ochrony języka, kultury i obyczajów wyniesionych z rodzinnego domu. Jak napisał w jednym z listów (3) do ordynariusza łódzkiego: „Na razie obowiązek pomagania rozproszonym rodakom zatrzymuje mnie w Niemczech". Przytoczone poniżej dokumenty egzemplifikują jego zmagania duszpasterskie wobec Boga, Kościoła i Ojczyzny. Nie są one pełnym zbiorem korespondencji ks. Wacława Tokarka kierowanym do swojego ordynariusza. Obejmują okres wyłącznie trzech lat. Niemniej są świadectwem jego pracy wśród rodaków obrazującym złożoność ówczesnej rzeczywistości. W niniejszej edycji pominięto korespondencję późniejszą ks. Tokarka.

Dokumenty oryginalne $\mathrm{w}$ formie rękopisu i maszynopisu przechowywane są w Archiwum Archidiecezjalnym w Łodzi (co zaznaczono w metryce każdego z nich), Teczka Personalna, sygn. 516, Ks. Tokarek Wacław. W publikacji źródeł zachowano oryginalny styl i składnię.

${ }^{3}$ K. Dopierała, ,, Stowo Katolickie”, w: Encyklopedia polskiej emigracji i Polonii, red. K. Dopierała, t. 4, Toruń 2005, s. 404.

${ }^{4}$ Archiwum Archidiecezjalne w Łodzi, Teczka Personalna, sygn. 516, Ks. Tokarek Wacław; Archiwum Polskiej Misji Katolickiej we Francji. G. Duszpasterze Misji - „Kapelani”, „Misjonarze emigrantów”, oraz zasłużeni działacze świeccy, 1923-, G. VIII. 2. Biogramy zmarłych duchownych: R. Mroziuk, Pożegnanie księdza prałata Wacława Tokarka, „Nasze Słowo”, 1990, nr 9 (5-12 VIII 1990), s. 6-7; P. Personalia. P. V. Akta osobisto duszpasterskie księży pracujących w ośrodkach duszpasterskich PMK we Francji, gromadzone po 1945. 276. Tokarek Wacław; P. VI. Ankieta personalna sporządzona w 1945 (-1955), 206. Tokarek Wacław, diec. łódzka; Ksiądz Wacław Tokarek, „Wiadomości Diecezjalne Łódzkie”, 11 (1990) s. 388; J. Dąbrowska, Pamięci ks. prat. Wacława Tokarka duszpasterza polskiej parafii w Dortmund-Eving, „Głos Katolicki”, 9 września 1990, s. 14; W. Szołdrski, Martyrologium duchowieństwa polskiego pod okupacją hitlerowska w latach 19391945, „Sacrum Poloniae Millenium”, 11 (1965) s. 264; Z. Turek, Spis księży pracujacych w duszpasterstwie polskojęzycznym w Niemczech w latach 1945-2005, w: Duszpasterstwo polskojęzyczne w Niemczech 1945-2005, red. S. Bober, S. Budyń, Lublin-Hannover 2006, s. 491-492; R. Mroziuk, Dortmund, w: Duszpasterstwo polskojęzyczne w Niemczech, s. 153. 
1945 listopad 29, Monachium - ks. Wacław Tokarek do bpa Włodzimierza Bronistawa Jasińskiego.

Źródto: AAL, Teczka Personalna, sygn. 516, rkps.

\section{Ekscelencjo! ${ }^{5}$}

Byłbym niezmiernie szczęśliwym, gdyby te moje kilka słów dostały się do rąk Waszej Ekscelencji i zaświadczyły o mojej czci i przywiązaniu do Jego Dostojnej Osoby.

Chciałbym jak najprędzej znaleźć się w diecezji. Na razie wykorzystuję moje studia dziennikarskie zdobyte dzięki łaskawości Waszej Ekscelencji.

Chciałbym zdobyte tutaj doświadczenie przy wydawaniu tygodnika użyć kiedyś w Ojczyźnie. Zasyłam wyrazy czci dla J.E. ks. biskupa [Kazimierza] Tomcza$\mathrm{ka}^{6}$ i całej Prześwietnej Kapituły.

$$
\begin{aligned}
& \text { Całuję ręce Waszej Ekscelencji } \\
& \text { i proszę pokornie o błogosławieństwo }
\end{aligned}
$$

\section{Ks. Wacław Tokarek}

Monachium-Freiman 29 - XI - 1945

${ }^{5}$ Urodził się 12 czerwca 1873 r. we Włocławku. Tam ukończył gimnazjum i rozpoczął naukę w seminarium duchownym, z którego przeniósł się do Akademii Duchownej w Petersburgu. 13 października 1895 r. przyjął świecenia kapłańskie z rąk bpa Aleksandra K. Bereśniewicza. Posługę duszpasterską jako wikariusz pełnił w Aleksandrowie Kujawskim i Kaliszu. Był proboszczem w Koninie i Piotrkowie Trybunalskim, a następnie rektorem seminarium w Łodzi. W dniu 21 sierpnia 1930 r. został biskupem diecezji sandomierskiej, a 30 listopada 1934 r. biskupem diecezji łódzkiej. Podczas okupacji został deportowany przez Niemców, przebywał poza diecezją. 20 grudnia 1946 na własną prośbę został zwolniony przez Stolicę Apostolską z kierowania diecezją. Rezydował w klasztorze redemptorystów w Tuchowie. Zmarł 17 kwietnia 1965 r. P. Nitecki, Biskupi Kościoła w Polsce w latach 965-1999, Warszawa 2000, k. 178-179; K. Dąbrowski, Arcybiskup Włodzimierz Jasiński 1873-1965, Łódź 1990.

${ }^{6}$ Urodził się 17 lutego 1883 r. w Biesiekierzu. Był wychowankiem Zakładu Naukowo-Wychowawczego Ojców Jezuitów w Chyrowie. Studiował m.in. w Akademii Duchownej w Petersburgu, Paryżu i Fryburgu. 7 stycznia 1907 r. przyjął świecenia kapłańskie. Był wikariuszem w Słomczynie i parafii katedralnej w Warszawie. Przez 16 lat pracował jako profesor w warszawskim seminarium duchownym. 25 lutego 1927 r. został pierwszym biskupem pomocniczym diecezji łódzkiej. W roku 1936 był jednym z założycieli Towarzystwa Przyjaciół Nauk w Łodzi. 6 września 1939 r. stanął na czele powołanego w Łodzi Komitetu Obywatelskiego. 9 listopada 1939 r. został aresztowany przez gestapo i osadzony w obozie przejściowym. 6 maja 1941 został internowany przez władze hitlerowskie. Był osadzony w klasztorze reformatów w Bieczu. Po powrocie do Łodzi pod koniec stycznia 1945 r., objął parafię Podwyższenia Św. Krzyża, którą kierował do śmierci. Jednocześnie pełnił obowiązki biskupa. 20 października 1957 r. podczas kazania w Piotrkowie Trybunalskim doznał wylewu krwi do mózgu, który skutkował paraliżem. Zmarł 21 października 1967 r. w Łodzi. S. Grad, M. Różański, Kapituła Katedralna Łódzka, Łódź 2007, s. 221-228. 


\section{2}

1945 maj 16, Monachium - Ks. Wacław Tokarek do bpa Wodzimierza Bronisława Jasińskiego

Źródto: AAŁ Teczka Personalna, sygn. 516; rkps

\section{Wasza Ekscelencjo!}

Korzystam z okazji, by przesłać Waszej Ekscelencji wyrazy najgłębszej czci i głębokiego synowskiego przywiązania.

Pracy tu jest wiele, księży coraz mniej. Każdy tęskni i w końcu woli powrót do domu, choćby tam było ciężko, aniżeli dalszą tułaczkę.

Słyszeliśmy, że w naszej diecezji jest dosyć księży, a więc jesteśmy tutaj potrzebniejsi aniżeli w kraju.

Całuję pokornie ręce Waszej

Ekscelencji i proszę o błogosławieństwo

Ks. W[acław] Tokarek

Monachium, 16 maja 1946.

1947 marzec 29, Monachium - Ks. Wacław Tokarek do bpa Michała Klepacza AAE, Teczka Personalna, sygn. 516

\section{Wasza Ekscelencjo! ${ }^{7}$}

Po otrzymaniu wiadomości, że Opatrzność powołała Waszą Ekscelencję na stolicę łódzkiego biskupstwa, spieszę przesłać Waszej Ekscelencji wyrazy hołdu i synowskiego przywiązania. Na razie obowiązek pomagania rozproszonym rodakom zatrzymuje mnie w Niemczech. Gdy moje tymczasowe władze kościelne zwolnią mnie, natychmiast chcę wracać, by pracować w swojej diecezji pod ojcowskimi rządami Waszej Ekscelencji.

\section{Całuję ręce Waszej Ekscelencji} i proszę o błogosławieństwo

Ks. Wacław Tokarek

Monachium 29 marca 1947.

${ }^{7}$ Bp Michał Klepacz urodził się 23 lipca 1893 r. w Warszawie. W dniu 2 czerwca 1916 r. przyjął świecenia kapłańskie z rąk bpa Jana Cieplaka w Petersburgu. W 1. 1942-1944 był aresztowany i więziony przez Niemców w obozie w Prawieniszkach na Litwie. W 1. 1944-1946 był profesorem seminarium duchownego w Wilnie i Białymstoku. 20 grudnia 1946 r. był prekonizowany na stolice biskupią w Łodzi. 28 września 1953 r., trzy dni po aresztowaniu prymasa S. Wyszyńskiego, na żądanie władz przejął przewodnictwo Konferencji Episkopatu Polski. Zmarł 27 stycznia 1967 r. w Łodzi. Nitecki, Biskupi Kościoła w Polsce, k. 203-204. 
1947 maj 14, [Łódź] - Bp Michat Klepacz do ks. Wacława Tokarka Źródto: AAE, Teczka Personalna, sygn. 516; mps, k.1.

\section{Drogi Księże!}

Z radością otrzymałem list Kochanego Księdza, który przekonał mnie, iż Bóg Dobry przechował Go wraz z innymi kapłanami i pozwolił znowu dla Królestwa Bożego pracować. Miłym i z tego względu było Jego odezwanie, że z całą szczerością pisze do mnie Drogi Ksiądz, pamiętając, iż przy święceniach kapłańskich przyrzekał mi szacunek i posłuszeństwo.

Cieszę się bardzo, że Drogi Ksiądz myśli o powrocie do Diecezji, która tylu kapłanów potrzebuje a której tak bardzo przydatni będą kapłani z otwartymi głowami, do których dobrze to wiem, i kochany Ksiądz należy. - Proszę przeto nie czekać, aż samorzutnie zwolnią Kochanego Księdza obecne władze kościelne, ale o to zwolnienie ubiegać się i przybyć do Diecezji, by pomóc współbraciom kapłanom, którym pomoc i współpraca bardzo jest potrzebna.

Bogu polecam Kochanego Księdza i w myśli już Go witam serdecznie przy warsztacie wspólnej pracy.

\section{Bp. M[ichał $\mathrm{K}[$ lepacz $]$}

\section{5}

1947 październik 6, Monachium - Ks. Wacław Tokarek do bpa Michała Klepacza AAŁ, Teczka Personalna, sygn. 516, k. 3, rkps.

\section{Wasza Ekscelencjo!}

Już raz odpowiedziałem na list Waszej Ekscelencji, ale dowiedziałem się że list mój wraz z mszałami i brewiarzami, które wysłałem dla Seminarium, zaginą1 w czasie rewizji transportu repatriantów. Raz więc jeszcze dziękuję za miłe słowa Waszej Ekscelencji. O powrocie do kraju marzymy wszyscy, ale nie możemy opuszczać ludzi, pozbawiając ich duszpasterskiej opieki. Z prawie 800 pracuje w Niemczech już tylko $186^{8}$. Wiele obozów jest bez duszpasterza.

Jest nam niezmiernie przykro, że praca nasza nie znajduje zrozumienia u niektórych księży biskupów. Głośnym echem odbiło się w Niemczech stanowisko

\footnotetext{
${ }^{8}$ W maju 1954 r. na terenie Niemiec Zachodnich pozostało 35 księży. Radomski, Demobilizacja Polskich Sit Zbrojnych na Zachodzie, s. 116.
} 
ks. bpa [Czesława] Kaczmarka ${ }^{9}$, a zwłaszcza ks. bpa [Lucjana] Bernackiego ${ }^{10}$ z Gniezna, który miał rzekomo powiedzieć, czy napisać, że wszyscy kapłani winni wracać, gdyż ludzie którzy nie wracają do Kraju nie zasługują na opiekę duszpasterską. Wywołało to wielkie oburzenie i niechęć do hierarchii. Wrogowie Kościoła wykorzystują to tutaj dla swej propagandy, że duchowieństwo zawsze popiera silniejszych, że biskupi teraz też nie potępiają wyroków śmierci, jak ongiś nie potępili Berezy itp. Piszę o tym, by dać obraz tutejszych nastrojów.

Ludzie mimo najbardziej wyrafinowanych metod nieświetnej pamięci UNRRA, nie chcą wracać. Zrobiono wszystko aby złamać ich opór. Nic nie pomogło. A warunki życia są bardzo ciężkie ${ }^{11}$. Widmo głodu staje w bramach obozów. W kraju wyobrażają sobie często (wynika to z opowiadań uciekinierów) że strefa

${ }^{9}$ Kapłan diecezji płockiej, od 24 maja 1938 r. biskup ordynariusz diecezji kieleckiej. Urodził się 16 kwietnia 1895 r. w Lisewie Małym k. Sierpca. Syn Józefa i Franciszki Bronisławy z d. Rogozińska. Po ukończeniu szkoły wiejskiej wstąpił do seminarium nauczycielskiego w Wymyślinie, a w roku 1917 do Wyższego Seminarium Duchownego w Płocku. 20 sierpnia 1922 r. przyjął święcenia kapłańskie z rąk bpa A. Nowowiejskiego. Od listopada podjął studia w zakresie socjologii na uniwersytecie w Lille, gdzie w 1927 r. uzyskał doktorat w Instytucie Nauk Społecznych i Politycznych. Podczas studiów prowadził też aktywną pracę duszpasterską wśród polskiej emigracji we Francji. Po powrocie do Polski w 1928 r., objął stanowisko sekretarza Związku Młodzieży Polskiej Męskiej, a następnie został dyrektorem płockiego Diecezjalnego Instytutu Akcji Katolickiej. 24 maja 1938 roku został biskupem diecezjalnym diecezji kieleckiej. 20 stycznia $1951 \mathrm{r}$. został aresztowany pod zarzutami szpiegostwa na rzecz Stanów Zjednoczonych oraz Watykanu. Został skazany na 12 lat więzienia. 2 kwietnia 1957 wrócił do Kielc. Zmarł 26 sierpnia 1963 r. w Lublinie. W roku 1990 został pośmiertnie uniewinniony i zrehabilitowany. Z uroczystości ingresowych $i$ konsekracyjnych J. E. Ks. Biskupa Czesława Kaczmarka, „Kielecki Przegląd Diecezjalny”, 9 (1938) s. 278-279; M. Grzybowski, Kaczmarek Czesław, biskup kielecki, w: Stownik Polskich Teologów Katolickich, t. 6, Warszawa 1983, s. 12-14; J. Śledzianowski, Kaczmarek Czesław, bp, w: Encyklopedia katolic$k a$, t. 8, kol. 307-309 (bibliogr.).

${ }^{10}$ Urodził się 12 lipca 1902 r. w Gościeradzu. W ostatniej klasie gimnazjum, wstąpił ochotniczo do Wojska Polskiego i w 1920 r., wziął udział w wojnie polsko-bolszewickiej. Po powrocie z wojska wstąpił do Wyższego Seminarium Duchownego w Gnieźnie. Studiował w Gdańsku, Gnieźnie i Poznaniu. 29 maja 1926 r. przyjął świecenia kapłańskie. Był wikariuszem w Trzemesznie i Poznaniu oraz notariuszem kurii archidiecezjalnej w Poznaniu. Kontynuował studia w Strasburgu i Rzymie. Był profesorem seminarium duchownego w Gnieźnie. Podczas okupacji pracował w duszpasterstwie Polaków we Francji, Hiszpanii, Portugalii i Wielkiej Brytanii. 4 września 1946 roku został biskupem pomocniczym archidiecezji gnieźnieńskiej. W 1948 r. został wikariuszem generalnym i kapitulnym archidiecezji. Deportowany z terenu archidiecezji, w 1. 1953-1956 przebywał w Częstochowie, Zaniemyślu i Poznaniu. Przez 29 lat był inwigilowany przez Służbę Bezpieczeństwa. Zmarł 28 września 1975 r. w Rzymie. Został pochowany na cmentarzu Św. Piotra i Pawła w Gnieźnie. W 2012 r. jego szczątki ekshumowano i przeniesiono do krypty biskupów pomocniczych archidiecezji gnieźnieńskiej. Nitecki, Biskupi Kościoła w Polsce, k. 27.

${ }^{11}$ „Ponad 350 tys. polskich dipisów ze stref zachodnich odmówiło powrotu do kraju. Polacy przebywający na terenie Niemiec zgrupowani zostali w kilkudziesięciu obozach pod opieką UNRRA. Warunki życia w obozach były ciężkie: skromne wyżywienie, monotonia, bezczynność, nuda, ograniczenie swobody poruszania się, demoralizacja i wzrost przestępczości oraz liczne zatargi z władzami okupacyjnymi”. cyt. za: Radomski, Demobilizacja Polskich Sił Zbrojnych na Zachodzie, s. $110-111$. 
amerykańska to kraina „dolarami i czekoladą” płynąca. Niestety czekoladę widzą tylko „czarni handlarze”. Księża muszą żyć w warunkach b. prymitywnych. Jeżeli mają jakiś własny kąt $\mathrm{w}$ obozie to są $\mathrm{b}$. zadowoleni. Po zupę z miską w ogonku. Często sam muszę urządzać pranie bielizny. Całe szczęście, że księża pracujący w Niemczech to b. kacetowcy. Mimo wszystko obóz D.P ${ }^{12}$. jest lepszy aniżeli koncentracyjny. Trudno jednak długo wytrzymać w tych warunkach i księża masowo wracają do kraju. W pierwszych miesiącach po wyzwoleniu było nienajgorzej. Kiedy ja wrócę? Nie wiem. Na wszelki wypadek proszę Waszą Ekscelencję o pozwolenie na ewentualny wyjazd na pracę wśród emigrantów, wyjeżdżających z Niemiec na Zachód.

Na razie pozostaję w Niemczech. Żal mi placówki z takim trudem stworzonej. Licencja na „Słowo” jest na moje nazwisko. „Słowo Polskie” przechrzciłem na „Słowo Katolickie”; bo takie wychodziło kiedyś w naszej diecezji. Tygodnik nasz ma charakter pisma popularnego, gdyż poziom większości uchodźców nie jest wysoki. Obecnie wolno wysyłać do Polski $2 \mathrm{~kg}$ paczki z drukami. Chętnie wysyłałbym miejscową prasę, ale nie wiem czy to komuś nie zaszkodzi.

Drukuję także dużo różnych obrazów i pocztówek. Słyszałem że o te rzeczy trudno w Polsce. Mógłbym je przesyłać, a pieniądze ze sprzedaży poszłyby na Seminarium Duchowne.

Mszały prześlę, ale tylko w małym formacie, pocztą. Tak samo brewiarze dla kleryków.

Przepraszam, że tak piszę chaotycznie, ale spieszę się, bo „okazja” zaraz odjeżdża.

\author{
Całuję ręce Waszej Ekscelencji \\ i proszę o błogosławieństwo \\ Ks. Wacław Tokarek \\ (Munchen Rotkreuspl. 3. I.)
}

Monachium 6 X 1947.

6

1947 październik 25, [Łódź] - bp Michat Klepacz do ks. Wacława Tokarka Źródto: AAE, Teczka Personalna, sygn. 516, mps, k.1.

25 października [19]47

Drogi Księże!

List Drogiego Księdza otrzymałem dzisiaj i z zainteresowaniem przeczytałem uwagi dotyczące duszpasterstwa wśród Polaków w Niemczech. Dziękuję

${ }^{12}$ Obóz uchodźców (osób wywiezionych na roboty przymusowe, więźniów obozów koncentracyjnych, jeńców wojennych, kilkudziesięciu tysięcy polskich dzieci wywiezionych w celach germanizacyjnych, byłych żołnierzy wermachtu, Polaków wpisanych na niemiecką listę narodowościową) - Displaced Persons, zwany DP - dipisami. Radomski, Demobilizacja Polskich Sił Zbrojnych na Zachodzie, s. 109-110. 
serdecznie za gotowość nadesłania mszalików i brewiarzy dla naszych kleryków, którzy w niełatwych warunkach sposobią się do kapłaństwa; w trudnych warunkach znajduje się i Diecezja, gdyż trzy lata jeszcze czekać musimy na święcenia naszych kandydatów do kapłaństwa.

W tej sytuacji sam Kochany Ksiądz rozumie, że powrót każdego kapłana do Diecezji rodzimej jest bardzo pożądany i dlatego też trzeba rozumieć troskę każdego z Ordynariuszów Polskich, którym zależy tak bardzo na obsadzeniu tylu placówek po parafiach i szkołach.

Bardzo pragnąłbym powitać i Drogiego Księdza w Diecezji swojej; jeżeli jednak osobiste jego warunki wymagają czasowego pozostania w Niemczech lub nawet wyjazdu dalej z naszymi rodakami, to - choć z trudnością - jednak godzę się na to, licząc, że głębokie zrozumienie potrzeb pracy duszpasterskiej w Ojczyźnie tak szybko każe mu do Diecezji powrócić, jak tylko będzie to możliwe.

Za obietnicę nadesłania czasopism bardzo jestem wdzięczny, czy jednak będzie to właściwe? Serdecznie drogiego Księdza pozdrawiam i błogosławię Jego pracy.

\section{Bp M[ichał] K[lepacz]}

\section{7}

1948 sierpień 28, Monachium - Ks. Wacław Tokarek do bpa Michała Klepacza Żródto: AAE, Teczka Personalna, sygn. 516, rps, k. 4.

\section{Wasza Ekscelencjo!}

Z radością korzystam z okazji, by przesłać znowu Waszej Ekscelencji swoje najserdeczniejsze wyrazy synowskiego przywiązania. O życzeniu Waszej Ekscelencji doniosłem naszym księżom, o których wiedziałem, że są jeszcze w Niemczech i których adresy znałem. My tutaj rozrzuceni na wielkich przestrzeniach mało wiemy o sobie. Z kolegami, którzy wyjechali do strefy brytyjskiej lub francuskiej nie widziałem się ani razu. Dopiero w Kurii we Frankfurcie dowiedziałem się, że niektórzy z nich wyjechali już do kraju. Warunki naszego życia są tu b. ciężkie. Gdyby nie szkoła jaką przeszliśmy w obozie, trudno byłoby wytrzymać. A jednak nie można opuścić tych ludzi ${ }^{13}$, których wojna bardzo zdemoralizowała. Kaplica i kapłan są duszą każdego obozu. My księża nie możemy prowadzić żadnej propagandy, ani za, ani przeciw. Każdy musi sam zdecydować o swym powrocie do kraju. Oczywiście władze amerykańskie i UNRRA stosują moralny przymus, by wracać14. Używa się do tego różnych sposobów, by ludzi zmęczyć. Nieprawdą jest, jakoby była jakaś agitacja za pozostaniem na emigracji ze strony

${ }^{13} \mathrm{~W}$ okresie II wojny światowej Niemcy deportowali ok. 3,5 mln Polaków do pracy sezonowej na terenie Rzeszy ( $75 \%$ do pracy i $25 \%$ ze względów politycznych). zob. M. Kiełczewska -Zaleska, A. Bonasewicz, Rozmieszczenie Polaków za granica, „Problemy Polonii Zagranicznej”, 1 (1960) s. 10.

${ }^{14}$ Zob. Radomski, Demobilizacja Polskich Sił Zbrojnych na Zachodzie, s. 109-116. 
czynników londyńskich. Przeciwnie ostatnio idą stamtąd coraz wyraźniejsze sugestie za powrotem. Mówi się, że wobec coraz mocniej zarysowującego się konfliktu (który może się odwlec) masy emigracji mogłyby się stać niepotrzebnym balastem. W kraju może łatwiej zdołają się uchować. Myśmy tyle ponieśli ofiar, że musimy się trzymać z dala od sporów wielkich tego świata. Jeśli się pobiją to nie o nas, ale oczywiście będziemy chcieli z tego wynieść jak najwięcej korzyści. Londyn w swoim ostatnim orędziu głosi, że zadaniem emigracji jest działanie, zadaniami kraju zachowanie biologicznych i duchowych sił. Wszelkie zamieszki są szkodliwe w tej chwili dla Polski. Stąd potępia się politykę Mikołajczyka ${ }^{15}$, który swoimi wystąpieniami naraża na zagładę najlepsze elementy. My sami swego losu nie zmienimy. Zależy on od sytuacji międzynarodowej. Przepraszam, że tak się rozwodzę ale chciałem choć w skrócie podać, o czym się u nas mówi.

Nie wiem co będzie z nami dalej. Prawdopodobnie część Polaków wyemigruje. Bawił ostatnio w Kurii arcybiskup z Australii. Powiedział, że będzie potrzebował 70 księży dla Polaków, którzy wyjadą do Australii. Być może, że pewien procent wyemigruje do Brazylii i Argentyny. Jeżeli z tymi ludźmi nie pojedzie ksiądz polski, to się łatwo wynarodowią. Czasem myślę, że może lepiej, by wrócili do kraju. Ci jednak zza Buga, którzy byli jakiś czas pod sowiecką okupacją nie chcą wracać za żadną cenę.

Zobaczymy co przyniosą najbliższe tygodnie. Ilu jeszcze wyjedzie, ilu zostanie. Na razie muszę tu być. Przy okazji przesyłam niektóre egzemplarze moich wydawnictw.

Uważam też za swój obowiązek określić krótko historię „Słowa Polskiego”. Po uwolnieniu nas przez wojska amerykańskie w Dachau, ks. [Jan] Warczak ${ }^{16}$,

${ }^{15}$ Mikołajczyk Stanisław - ur. 18 lipca 1901 w Dorsten-Holsterhausen, zm. 13 grudnia 1966 r. w Waszyngtonie - przywódca Polskiego Stronnictwa Ludowego, poseł na Sejm II RP (III kadencji), premier rządu RP na uchodźstwie, po II wojnie światowej poseł do Krajowej Rady Narodowej i na Sejm Ustawodawczy, wicepremier i minister rolnictwa w Tymczasowym Rządzie Jedności Narodowej. Zagrożony aresztowaniem i ostrzeżony, 20 października 1947 r. za pośrednictwem urzędników ambasady USA został dowieziony do Gdyni i przemycony na pokład statku Baltavia, na którego pokładzie opuścił polskie wody terytorialne, udając się do USA. Nie został przywódcą emigracji, po przybyciu na Zachód, pozostał w izolacji politycznej.

${ }^{16}$ Urodził się 3 września 1906 r. w Śliwicach Wielkich k. Tucholi. Szkołę powszechną ukończył w rodzinnej miejscowości. Wykształcenie średnie otrzymał w Seminarium Nauczycielskim w Grudziądzu i Kolegium Misjonarzy Świętej Rodziny w Wieluniu i Górce. Po uzyskaniu świadectwa dojrzałości dwa lata studiował filozofię w Seminarium Duchownym w Łodzi (1925-1927), a następnie teologię w Instytucie Katolickim w Paryżu (1927-1929). 1 września 1929 r. w Łodzi przyjął święcenia kapłańskie. Przez kolejne lata był prefektem w łódzkich szkołach: Gimnazjum Niemieckim Męskim (1929-1931), Gimnazjum Żeńskim im. E. Orzeszkowej (1929-1930) i Gimnazjum Żeńskim A. Rothert (1929-1930). W 1930 r. obronił pracę doktorską w Instytucie Katolickim w Paryżu. W 1. 1930-1931 pełnił obowiązki wikariusza parafii Św. Krzyża w Łodzi. Od 1931 do 1937 r. był katechetą w Piotrkowie Trybunalskim. Uczył w Państwowym Seminarium Żeńskim (1931-1937), Szkole Handlowej Związku Nauczycielstwa Polskiego (1931-1937) oraz w szkole powszechnej (1932-1937). W sierpniu 1937 r. został przeniesiony do Łodzi. Objął zajęcia z homiletyki i pedagogiki, a rok później z katechetyki w Seminarium Duchownym. Równocześnie uczył religii w Gimnazjum H. Miklaszewskiej. Tuż po rozpoczęciu II wojny światowej został rektorem 
o. [Piotr] Turbak ${ }^{17}$, ks. [Henryk] Demrych ${ }^{18}$ i ja postanowiliśmy wydawać pismo religijne „Polska Chrystusowa” na powielaczu. Ja jednak w tym samym czasie objąłem redakcję pisma świeckiego „Słowo Polskie”, którego pierwszy numer ukazał się 3 maja $1945 \mathrm{r}$.

„Polskę Chrystusową” prowadził ks. Warczak Jan, po nim zaś ks. Jaroszka Lucjan $^{19}$. Obecnie zaś po przejściu ks. Jaroszki do mojego „Słowa Polskiego”,

Seminarium Duchownego. Po rozwiązaniu seminarium organizował tajne studia dla kleryków nie wysiedlonych z Kraju Warty. Od 29 lutego 1940 r. został administratorem parafii św. Jana Chrzciciela w Nowym-Złotnie. 7 marca 1941 r. w Łodzi został aresztowany przez Niemców. Przebywał w więzieniu w Łodzi, Poznaniu (od 1 sierpnia 1941 r.), a następnie w obozach koncentracyjnych w: Mauthausen (od 15 sierpnia 1941 r.), Dachau (od 30 maja 1942 r. - nr obozowy 30241). Po wyzwoleniu, 31 maja 1945 przybył do Francji, przebywał w Paryżu jako kapelan nazaretanek i duszpasterz akademicki studentów - Polaków. W lutym 1950 r. wyjechał do Kanady. Przez trzy lata pracował wśród Polaków w diec. St. Paul (najdłużej jako proboszcz w parafii Vilna). W roku 1952 został rektorem Wyższego Seminarium Duchownego w Archidiecezji Saint Boniface, Manitoba. Był również kapelanem Misericordia Hospital oraz oficjałem diec. Winnipeg. Z powodu choroby przeniósł się do St. Mary’s Academy. Zmarł w Winnipeg 23 kwietnia 1964 r. AAŁ, Teczka Personalna, sygn. 284, Ks. Warczak Jan; Archiwum Polskiej Misji Katolickiej we Francji. P. Personalia. VI. Ankieta personalna kleru polskiego pracującego we Francji. 3. Ankieta personalna z 1945, R-Z. Warczak Jan; Szołdrski, Martyrologium duchowieństwa polskiego, s. 76; E. Weiler, Die Geistlichen in Dachau sowie in anderen Konzentrationslagern und in Gefängnissen, Mödling 1971, s. 692; M. Budziarek, „, Gloria Victis” Martyrologia wykładowców łódzkiego Seminarium Duchownego podczas okupacji hitlerowskiej 1939-1945, „Łódzkie Studia Teologiczne”, 1 (1992) s. 21-27; Polska Kronika Zagraniczna, „Duszpasterz Polski Zagranicą”, 5 (1954) z. 2 (19) s. 210; J. Czech, Ocalić od zapomnienia. Sylwetki nauczycieli tajnego nauczania w latach 1939-1945, Łódź 2014, s. 91-94.

${ }_{17}$ Urodził się 3 kwietnia 1890 r. w Dąbrowicy k. Tarnobrzegu. Syn Andrzeja i Agnieszki z d. Lis. Do zakonu jezuitów wstąpił 14 lipca 1906 r. Święcenia kapłańskie przyjął 15 sierpnia 1920 r. Aresztowany został przez Niemców w Krakowie 10 listopada 1939 r. Przebywał w więzieniu w Krakowie-Montelupich, Wiśniczu (od 3 lutego 1940 r.), Oświęcimu (od 20 czerwca 1940 r.), Dachau (od 12 grudnia 1940 r. - nr obozowy 22245). Po wyzwoleniu podjął posługę duszpasterską w Niemczech i Francji (Coueron 1946-1947). Zmarł 4 października 1966 r. Encyklopedia wiedzy o jezuitach na ziemiach Polski i Litwy 1564-1995, red. L. Grzebień SJ, Kraków 1996, s. 703; Szo1drski, Martyrologium duchowieństwa polskiego, s. 258; Weiler, Die Geistlichen in Dachau, s. 674.

${ }^{18}$ Orionista. Urodził się 13 października 1904 r. w Łodzi. Święcenia kapłańskie przyjął 29 czerwca 1928 r. Od 1931 r. kierował Drukarnią Diecezjalną i Księgarnią Powszechną we Włocławku. Od 1934 r. organizował duszpasterstwo i parafię we Włocławku-Grzywnie. Aresztowany został przez Niemców we Włocławku 7 listopada 1939 r. Przebywał w więzieniu we Włocławku, Lądzie, Szczeglinie (od 26 sierpnia 1940 r.), Sachsenhausen (od 29 sierpnia 1940 r.), Dachau (od 14 grudnia 1940 r. - nr obozowy 27830). Szołdrski, Martyrologium duchowieństwa polskiego, s. 76; Weiler, Die Geistlichen in Dachau, s. 197.

${ }^{19}$ Urodził się 30 kwietnia 1913 r. w Pabianicach. Syn Brunona i Florentyny. W 1933 r. podjął studia na Wydziale Prawa Uniwersytetu A. Mickiewicza w Poznaniu, które przerwał i wstąpił do Wyższego Seminarium Duchownego w Łodzi. 2 lipca 1939 r. w Łodzi z rąk bpa Włodzimierza Jasińskiego przyjął święcenia kapłańskie. Od pierwszych dni wojny włączył się w pracę konspiracyjną. 6 grudnia 1939 r. został wikariuszem parafii św. Mateusza w Pabianicach i był jednocześnie kapelanem szpitala przy ul. Żeromskiego. 28 października 1940 r. został wikariuszem w Kurowicach. Za działalność konspiracyjną został aresztowany 6 lutego 1943 r. i osadzony w obozie koncentracyjnym w Mathausen 16 czerwca 1943 r., a następnie w Dachau do 29 kwietnia 1945 r. - nr 
„Polskę Chrystusową” redaguje o. Turbak. Od roku „Słowo Polskie” wychodzi już drukiem i wyrosło na najpoważniejsze czasopismo w strefie amerykańskiej ${ }^{20}$.

Wydajemy periodyki „Słowo Polskie” - tygodnik ilustrowany „Byle prędzej” - biuletyn codzienny „Słówko Polskie” - dwutygodnik dla dzieci i „Słowo Boże” - niedzielny biuletyn religijny. Wydajemy także różne książki: 1 . „Repatriacja na księżyc” - felietony, 2. „Resztki z kamieni” - H. Zybała - wiersze, 3. „Śpiewajmy Panu” - ks. I. Wojewódka, 4. „Kościół naród i państwo - R. Dmowski, 5. „W pogoni za nieskończonością", 6. Album K-Z., 7. Album Warszawy. W druku mamy: „Pieskie rozważania”, 2. „ABC Polaka”, 3. „Tysiąc lat polskiej polityki” - Wasiutyński, 4. „Dyplomacja w Dachau” - Grabiński, 5. „Quo vadis” - wydanie luksusowe, 6. Historia literatury, 7. Podręcznik szoferski, 8. Nowele Żeromskiego.

I to wszystko trzeba robić zwalczając najróżniejsze przeszkody. Nie mieliśmy od nikogo pomocy. Nawet od Kurii. Rozpoczęliśmy dosłownie z niczym. Później otrzymaliśmy trochę pieniędzy od czytelników. Ponieważ zaś nie płacimy nikomu pensji, zdobyliśmy pewien majątek obrotowy. Władze krajowe w osobach misji repatriacyjnej dotychczas nam nie przeszkadzały, ale zawsze się boję że stamtąd przyjdzie ktoś, który zniszczy nasz dorobek mimo, że jak ognia unikamy wszelkiej polityki. W pracy pomaga mi ks. Jaroszka i ks. Ignacy Wojewódka ${ }^{21} z$ diecezji pomorskiej.

Jakby to było pięknie, gdyby można wydawać różne pisma w kraju.

Tutaj również wielką bolączką jest brak papieru.

Wasza Ekscelencja wybaczy różne usterki tego listu, ale chciałbym wiele napisać i stąd też wkradł się może pewien chaos.

134376. Po uwolnieniu z obozu w Dachau pracował jako duszpasterz dla polskich wysiedleńców w Monachium, Dillingen i Ingolstadt. Jednocześnie współpracował w 1945 r. z redakcją „Polski Chrystusowej”, a w 1. 1946-1947 z redakcją „Słowa Katolickiego”. W 1950 r. wyjechał do Australii. Podjął pracę w diecezji Sale we Wschodniej Wiktorii, a od 1954 r. objął opiekę duszpasterską nad Polską Wspólnotą w Geelong. Z jego inicjatywy powstał „Przegląd Katolicki”, współpracował przy jego redakcji. W 1974 r. Polską Wspólnotę w Geelong przekazał księżom chrystusowcom. Powrócił do kraju. Zamieszkał przy parafii św. Mateusza w Pabianicach, k. Łodzi. Zmarł 4 lipca 1995 r. w Szpitalu Miejskim w Pabianicach. Pochowany został na cmentarzu parafialnym w Pabianicach. AAŁ, Teczka Personalna nr 533, Ks. Jaroszka Lucjan; J. Szymański, Duszpasterze Polonii i Polaków za granica. Stownik biograficzny, t. 1, Lublin 2010, s. 64-66.

${ }^{20}$ Zob. Nadolny, Opieka duszpasterska nad dziećmi i młodzieża polska na terenie Niemiec Zachodnich, s. 92-96.

${ }^{21}$ Urodził się 27 sierpnia 1908 r. w Starej Kiszewie. Gimnazjum ukończył w Kościerzynie, a studia filozoficzno-teologiczne w Wyższym Seminarium Duchownym w Pelplinie. W dniu 15 czerwca 1935 r. z rąk bpa Stanisława Okoniewskiego przyjął świecenia kapłańskie. Obowiązki duszpasterskie podjął jako wikariusz w Gdyni-Obłożu. Od 1936 r. samodzielnie organizuje wspólnotę parafialną w Toruniu-Mokrym. 20 września 1939 r. został aresztowany przez gestapo. Więziony w obozach koncentracyjnych: Stutthof, Sachsenhausen i Dachau. Od początku 1945 r. pracował w redakcji „Słowa Katolickiego” i „Słowa Polskiego” (München). Równocześnie obejmował opieką duszpasterską Kompanię Wartowniczą w Neubiberg i pomagał w duszpasterstwie wśród Polaków w Monachium. Zmarł 25 stycznia 1954 r. w Madrycie (Hiszpania). Pochowany został w Paryżu. na cmentarzu Montmorency. Śp. Ksiądz Ignacy Wojewódka, „Duszpasterz Polski Zagranicą”, 5 (1954) z. 2 (19) s. 200; Weiler, Die Geistlichen in Dachau, s. 698. 
Jeszcze raz zapewniam, że jeżeli moje tutejsze władze duchowne uznają że jestem niepotrzebny natychmiast wracam do diecezji.

\title{
Całuję ręce Waszej Ekscelencji
}

\author{
Ks. Wacław Tokarek
}

Monachium 28 -VIII - 48.

Słowa kluczowe: Ks. Tokarek Wacław, duszpasterstwo polonijne, redaktor m.in. „Słowo Katolickie”, „Słowo Polskie”. „Polska Wierna”

\section{REV. WACŁAW TOKAREK - IN THE SERVICE OF ONE CHURCH}

\section{Summary}

Rev. Wacław Tokarek was a priest of the Archdiocese of Łódź. He was born on January 15, 1914 in Łódź. On August 15, 1936 he was ordained a priest by Bishop W. Jasiński. On October 6, 1941 he was arrested by the Gestapo in Pabianice. He was imprisoned at Dachau concentration camp. He worked for the Poles in Munich and the region near this city. He was an editor of, among others, „Słowo Katolickie”, „Słowo Polskie”. In 1950 he went to France, where he edited the magazine: „Polska Wierna” and „Słowo Katolickie”. He helped in pastoral work in Paris. In 1969 he returned to Germany, where he settled permanently. On

1 November 1970 he became a parish priest of the Polish Catholic Mission in Dortmund. He died there on July 2, 1990.

Immediately after the liberation of the camp, he began ministering to his countrymen. By sharing their wanderer's fate through the written word, he provided opportunities to protect the language, culture and customs learnt in the family home. The documents cited below exemplify his pastoral struggle in the service of God, the Church and the country.

Keywords: Rev. Wacław Tokarek, chaplaincy of the Polish community abroad, an editor of „Słowo Katolickie”, „Słowo Polskie”, „Polska Wierna” 